\title{
Innovative pedagogical practices using ICT - results of the German SITES-M2
}

\author{
Rebekka Dalmer, Thomas Petzel and Renate Schulz-Zander \\ Institute for School Development Research, University of Dortmund, Vogelpothsweg 78, D- \\ 44221 Dortmund, Germany
}

schuza@ifs.uni-dortmund.de

Key words: Classroom Teaching/Practice, Innovation, Research, Students, Teacher

\begin{abstract}
The international SITES-Module 2 (Second Information Technology in Education Study) of the International Association for the Evaluation of Educational Achievement (IEA) is a qualitative study of innovative pedagogical practices that use Technology in schools in 28 countries. The investigation was carried out in 2000/2001. Twelve case studies have been conducted in primary, lower and secondary schools in Germany. Results of the German SITES-M2 concerning the outcome of teacher and student practices are presented and discussed in the paper.
\end{abstract}

\section{INTRODUCTION}

The international study Second Information Technology in Education Study (SITES), of the International Association for the Evaluation of Educational Achievement (IEA), covers a research programme comprising three modules (Pelgrum and Anderson 1999). SITES-Module 2 is a qualitative study that aims at identifying, analysing and documenting innovative forms of teaching and learning worldwide that include the use of ICT and where that use is outstanding. Case-studies on innovative pedagogical practices with the use of ICT were carried out in schools in 28 countries in 2000/2001. The results supply decision makers and teachers

The original version of this chapter was revised: The copyright line was incorrect. This has been corrected. The Erratum to this chapter is available at DOI: 10.1007/978-0-387-35663-1_34 
with exemplary teaching practice illustrating the use of ICT and with findings on the factors which are necessary for the successful implementation of ICT and its sustainability. They contribute to the development of educational theory and will assist the implementation of SITES-M3. This paper presents selected results from the German SITESM2.

\section{RESULTS OF THE GERMAN SITES-M2}

For the evaluation of the comprehensive results, the international analysis scheme was used. The system of categories stipulated by this scheme was applied for each individual case. The analysis scheme covers different levels of analysis. The core field of the case reports, and therefore also of the crosscase analysis, relates to the so-called micro-level: the specific activities of the teachers and students during the implementation stage of the innovation. First of all the essential characteristics of the activities of the people involved are described. Then the effect of the innovation on both the students and the teachers is examined to identify how those involved profit from the innovation. Problems and obstacles that may occur during the implementation phase of the innovation, and estimates concerning the sustainability of the innovation, are given. For example we wish to identify the conditions which have to be fulfilled to integrate innovative uses of ICT into teaching which are sustainable.

\subsection{Teacher Practices and Outcomes}

Questions such as which specific activities do teachers carry out during the innovation and what affect does the innovation have on those involved are dealt with in this category. 'Teacher practice' covers both the preparation of the teacher for the innovative practice and the actual activities carried out during the realization of the lesson. During the period of innovation, the teacher takes up an advisory, guiding or instructing role and also provides the structure for the activities of the students. The interviewees involved in all the case studies either mention these two characteristics of teaching activity or the characteristics could be observed during the visits to see the lessons (Table 1).

"The idea is that we organise, i.e. provide cause for learning and organise its framework conditions. The impetus is then given and they work until they are through and we proceed to our next duty of evaluating the whole work. In-between, we are helpers when consulted." (Teacher DE003) 
Table 1. Teacher Activities

\begin{tabular}{lcccc}
\hline \multicolumn{1}{c}{ Activity } & $\begin{array}{c}\text { Total Case } \\
(12)\end{array}$ & $\begin{array}{c}\text { Cases - } \\
\text { Primary (4) }\end{array}$ & $\begin{array}{c}\text { Cases - Lower } \\
\text { Secondary (4) }\end{array}$ & $\begin{array}{c}\text { Cases - Upper } \\
\text { Secondary (4) }\end{array}$ \\
\hline Lecture & 11 & 3 & 4 & 4 \\
$\begin{array}{l}\text { Advise or guide students } \\
\begin{array}{l}\text { Create structure for } \\
\text { student activities }\end{array}\end{array}$ & 12 & 4 & 4 & 4 \\
$\begin{array}{l}\text { Design and prepare } \\
\text { instructional material }\end{array}$ & 9 & 4 & 4 & 4 \\
$\begin{array}{l}\text { Monitor and/or assess } \\
\text { student performance }\end{array}$ & 9 & 4 & 2 & 4 \\
$\begin{array}{l}\text { Collaborate with students } \\
\text { Collaborate with }\end{array}$ & 6 & 3 & 2 & 1 \\
$\begin{array}{l}\text { colleagues } \\
\begin{array}{l}\text { Collaborate with external } \\
\text { actors }\end{array}\end{array}$ & 7 & 3 & 2 & 3 \\
\hline
\end{tabular}

In 11 of 12 cases the teachers adopted, at some time, the classic role of the teacher, imparting knowledge in the traditional ex-cathedra manner. Excathedra teaching was considered necessary, especially in the introductory phases of an innovative lesson to offer a starting point for the teachers' work with the students. In the course of the lesson there are always teacher-centred phases in which the results of the students' work are being collected and new tasks are set for the students. The following quotation illustrates the two poles of teacher activity - ex-cathedra teaching on the one hand and the adoption of a more restraining, background role that gives enough freedom for independent work to the students on the other:

"Frontal teaching is inevitable, it must be introduced. Else, I will try to make the children work independently and as much as possible always with assistance. In every teaching form, there are always children who feel at home with the method and others who have difficulties." (Technical Coordinator DE009)

If you distinguish the different activities of the teachers by grades, a more differentiated picture may be discerned (Table 1). In most cases teaching activity includes the 'design and preparation of instructional material'. Many of the teachers who were interviewed pointed out that there is no instructional material available for their innovative work with ICT that they can fall back on. In the majority of cases the teachers said that the checking or rating of student performance was a further substantial activity. Changes in cooperation of teachers with students were explicitly mentioned in six cases and seem to be a characteristic of innovation, particularly in 
elementary schools (in 3 cases). With regard to the case studies in upper secondary, cooperation with actors outside of the classroom seems to be an essential characteristic of the changes that have taken place.

To sum up it may be said that in all cases, the teachers adopt an advisory and guiding role in their teaching and that they are responsible for the structuring of student activities. In the observed innovative pedagogical practices, phases of teacher-centred practice take turns with phases that promote (and require) greater student independence. In the latter phase teachers withdraw themselves more and the students control their own learning and work-processes.

Table 2. Impacts of innovation on teachers

\begin{tabular}{lcccc}
\hline \multicolumn{1}{c}{ Impacts } & $\begin{array}{c}\text { Number of } \\
\text { Cases }\end{array}$ & $\begin{array}{c}\text { Cases - } \\
\text { Primary }\end{array}$ & $\begin{array}{c}\text { Cases - Lower } \\
\text { Secondary }\end{array}$ & $\begin{array}{c}\text { Cases - Upper } \\
\text { Secondary }\end{array}$ \\
\hline New pedagogical skills & 11 & 3 & 4 & 4 \\
ICT skills & 7 & 2 & 3 & 2 \\
Collaborative skills & 4 & 1 & 1 & 2 \\
Positive attitudes & 7 & 2 & 3 & 2 \\
towards the teaching & & & & \\
profession & 5 & 2 & 1 & 2 \\
Negative outcomes & & & & \\
\hline
\end{tabular}

The impact of the innovation on the teachers can be divided into different fields (Table 2). In connection with the realized innovations, most of those interviewed reported that they acquired new skills, pedagogical as well as technical, and experienced a change of attitude towards the events in teaching. On the basis of the given data it is not possible, though, to comment on the causality of this process - are the acquisition of new skills or attitudes an impact of the innovations or a prerequisite for their realization? Equally it was not possible to conclude that it was a reciprocal process of mutual influence between concrete practice and new skills.

In almost all cases it was reported that the innovation fostered the acquisition of new pedagogical skills. The teachers were able to teach in a project-oriented and open way.

"I am relatively new to the school and did not lay such emphasis on project-orientated lessons. The amount of lessons that now take on this form has risen due to the use of computers in the classroom. I have developed a new style of teaching. I now have the possibility to go about it in a different way. You have to go through this inner process and think in a different way." (Teacher DE006)

The teachers have learned to handle their new role as an 'advisor' and 
'tutor'.

"[One has to] adjust himself to the new role of the teacher. The [traditional role of teachers] is a different one. It is such with a tendency of constantly standing behind the student to see what he is doing. And when one is then sitting there like I was and no one wants anything from you, it is somehow awkward. One feels useless. One simply has to stand the situation." (Teacher DE015)

A new teaching situation develops from this. Consequently teachers have had to adapt to changed requirements of their role. They must be able to handle new situations in their classrooms.

"That is a very intimate pedagogical situation, where you do not always need the teacher as an authority. I have learned very much. .... Today I am much more moderate in my references. In the past it was: "You cannot do it this way! This is totally wrong!" Today I would say: "Just think about it again - do you think that it is right this way?" Today I am also much more flexible and can think in terms of alternatives." (Teacher DE015)

In only one case the realized innovation was not accompanied by the acquisition of new pedagogical skills. This can be traced back to a ceilingeffect: the teachers in this school had been working with open or projectoriented forms of teaching for quite some time. Consequently the innovative work did not lead to the acquisition of new pedagogical skills.

Similarly, the acquisition of ICT skills as a concomitant of the innovation was mentioned in seven cases. In the remaining five cases knowledge of the use of ICT existed already so that the teaching activities could not increase it.

In five cases the teachers reported negative outcomes from innovation. In the first place, greater time and work expenditure was mentioned in the context of innovative work. Apart from creating new instructional materials it was also found extremely time-consuming to develop the use of ICT to integrate it innovatively into teaching. Some interviewed teachers identified a further negative outcome in the fact that due to the trial status that they are in as they are trying something new, they feel that it is more than they can handle. In addition, the realization of the innovative pedagogical approach requires more concentration from the teacher. The empirical findings within the scope of the evaluation of the German initiative "Schulen ans Netz" (Schools Online), carried out by the Institute of School Development Research at the University of Dortmund in 1999, show teachers noted that teaching itself is felt to be more demanding although it is more fun 
(Huneshagen et al 2000; Schulz-Zander 2001).

\subsection{Student Practices and Outcomes}

In this section student activities during the period of innovation, as well as the impacts of the innovation on the students, are characterized (Table 3).

Table 3. Student activities

\begin{tabular}{lcccc}
\hline \multicolumn{1}{c}{ Activity } & Total Cases & $\begin{array}{c}\text { Cases - } \\
\text { Primary }\end{array}$ & $\begin{array}{c}\text { Cases - Lower } \\
\text { Secondary }\end{array}$ & $\begin{array}{c}\text { Cases - Upper } \\
\text { Secondary }\end{array}$ \\
\hline Drill and practice tasks & 1 & 1 & 0 & 0 \\
Research projects & 3 & 0 & 2 & 1 \\
Search for information & 9 & 2 & 4 & 3 \\
$\begin{array}{l}\text { Solve problems } \\
\text { Manipulate/interpret }\end{array}$ & 1 & 0 & 0 & 1 \\
data & 2 & 0 & 0 & 2 \\
$\begin{array}{l}\text { Publish/present results } \\
\text { Design and create }\end{array}$ & 10 & 3 & 4 & 3 \\
products & 11 & 4 & 4 & 3 \\
$\begin{array}{l}\text { Collaborate } \\
\text { Collaborate with }\end{array}$ & 12 & 4 & 4 & 4 \\
external actors & 6 & 2 & 2 & 2 \\
$\begin{array}{l}\text { Assess own/peer } \\
\text { performance }\end{array}$ & 5 & 1 & 2 & 2 \\
Select own tasks & 9 & 3 & 4 & \\
\hline
\end{tabular}

The cooperation between the students was considered an important characteristic. The students mainly worked together in small groups or with a partner. The organisation of group work in the innovation class is described:

"We should undertake more with each other. In the past, we mostly, had individual work. Now, everything is done in groups: a reason for everyone to get along with each other. Table groups are always put together randomly. Lots are cast. Thereafter, one has to get along with them and do group work with them for three months. We do not do group work only with table groups, but also with them. The groups should be able to get along in this case." (Student DE003)

Much student activity consisted of designing and creating products as well as in publishing or presenting their results (PowerPoint presentation, posters, fairy tale book, homepage, newspaper).

In many cases, students searched for information - either in electronic media (Internet, CD-ROM) or print media (books, magazines). In most 
cases, students had the opportunity to at least partially have a say in the assignments they were set. The students were able to choose from a bigger collection of possible assignments.

With regard to the effects of the innovations on the students it was found that skills of cooperative working were promoted in almost all cases (Table 4):

Table 4. Impacts of innovation on students

\begin{tabular}{lcccc}
\hline \multicolumn{1}{c}{ Impacts } & Total Cases & Cases Primary & $\begin{array}{c}\text { Cases - Lower } \\
\text { Secondary }\end{array}$ & $\begin{array}{c}\text { Cases - Upper } \\
\text { Secondary }\end{array}$ \\
\hline New subject matter & 7 & 2 & 2 & 3 \\
ICT skills & 12 & 4 & 4 & 4 \\
Communication skills & 7 & 2 & 3 & 2 \\
$\begin{array}{l}\text { Problem solving } \\
\text { skills }\end{array}$ & 1 & 0 & 0 & 1 \\
Information handling & 8 & 2 & 4 & 2 \\
skills & & & & \\
Team/collaborative & 11 & 4 & 3 & 2 \\
skills & & 3 & 3 & 2 \\
Metacognitive skills & 8 & 4 & 4 & 2 \\
Increased motivation & 10 & 1 & 2 & 1 \\
$\begin{array}{l}\text { Outcomes for } \\
\text { different groups }\end{array}$ & 5 & 1 & & \\
Negative outcomes & 3 & & & \\
\hline
\end{tabular}

"Last year, the students learnt to work in groups. .... The students work together in a proper and astoundingly disciplined manner. Yesterday when I came too late, the students were seated and had started working. Under normal circumstances, no one does that in the eighth class. .... It raises the degree of self-dependability. .... They agree on appointments for meeting at home or simply begin to work." (Teacher DE003)

The independence of the students increased considerably due to the innovative work. They were increasingly able to control their learning process. In two thirds of the cases it was explicitly stated that the development of meta-cognitive skills or self-learning competences was promoted by the innovations.

It was also reported that in most cases the students worked and learned with increased motivation as a result of the innovation. This is shown by the following quotation. It also illustrates the way that the use of ICT affects lower-performing students (according to the opinion of some teachers):

"Especially children with extremely low performance took great profit out of working with the computer. Children who were almost functionally 
illiterate devotedly wrote with the computer. Motivation is extremely important here. They suddenly liked to do things they had actually hated before and they had better results, too. .... I think this is because they can always revise their work until it is good and rounded." (Technical Coordinator DE007)

In all the cases, the interviewees reported that the students improved their skills in the use of ICT. The following quotation not only comments on the acquisition of ICT skills but also on the development of information handling skills:

"Media competence is for me the active participation in this media society. Not only as consumer, also as producer. That's why I produce with the students whatever I can. In this way, they learn that is it possible to do a radio broadcast, or a video. They now look at these things in a different way. They suddenly see camera angles and say: "That is so cheap, that hasn't happened, this has been made without effort"." (Teacher DE013)

Among the positive impacts, a few negative outcomes were described. Fear was expressed that the innovative practice with ICT would reinforce differences in performance - both between students that have access to ICT at home and those without access at home on the one hand, and between students who were low or high performing even before the innovation began:

"For me there is a problem with a widening gap. You know, it's widening because if somebody has access to the net they do that really fast. Somebody who can't do it in the first place won't have the guts to sit down and try". (Teacher DE002)

"There is a difference between students who are good and those that are weak at learning. Here however, the fact already known by us about the open and closed forms of teaching is reproduced, namely that students who are apparently good at learning, motivated and highly cognitively qualified, are more at home with all forms of independent demands than those that are weak at learning and require more guidance. Since I celebrate the usage of computer as a means of opening up, it may be possible that they indeed, suffer a setback if one looses sight of this fact." (School Principal DE002)

Concern was also expressed about the "open-teaching" and how students experiencing this appeared to lack orientation. 


\section{PROBLEMS AND SOLUTIONS}

The innovative pedagogical practices are often accompanied by problems. These problems, though, were, at least partly, resolved by the schools we investigated. In the first place these problems relate to the field of technical infrastructure. On one hand some schools find it difficult to finance the necessary hardware (4 cases) and this in turn is closely connected to the resulting low level of technical equipment (3 cases). Insufficient support by the supervisory school authority was criticised in many cases although due to the sponsorship raising activities of the principal it was possible to find mezzanine money. On the other hand technical support was considered a problem in four cases. There are few technicians who are responsible for the administrative matters associated with equipment in schools so this task falls to the teachers. Some schools have solved the problem by employing technicians.

A further set of problems affects all teachers. The burden of time to devote to innovative work was considered a problem in 4 cases. In 5 cases the teachers who were not involved in the innovation were critical at the beginning of the programme. They were envious of the equipment supplied to the innovation classes and annoyed that they had to teach extra lessons, for example when the innovation teachers were absent because of European school exchanges or attending coordination meetings. The teaching staff also expressed some scepticism of the innovation.

A further difficulty in three reported cases was that the timetables were too cramped. According to the interviewees, the 45-minute-rhythm of the timetable prevented the self-controlled work process of the students. On top of this, time restraints made multidisciplinary work more difficult. In one school this led to the establishment of a weekly project day where the usual division into several lessons was removed. This project day is particularly used for multidisciplinary work on projects. It is also used for more complex projects in individual subjects. Organisational problems were not always resolved but they did not prevent the sustainability of the innovative teaching practices.

\section{CONCLUSION - SUSTAINABILITY OF THE INNOVATIONS}

The data and findings that were gained within the scope of the case studies led to the conclusion that the sustainability of innovations mainly depends on the commitment of the involved teachers to continue the innovative activity. In one school it was considered important that there was 
a teacher who was most involved in the project and who acted as a driving force for the other teachers who were involved. According to two cases, the further training of the teaching staff in order to expand knowledge of innovative teaching techniques and of ICT is also important for this commitment.

Interviewed teachers also commented that it was important for the sustainability of the innovations that support for the innovation from the principal is guaranteed (3 cases), that innovation must be supported by all the teaching staff ( 3 cases) and that innovative work should be accepted by the parents (one case). The codification of the innovative teaching practices into in-school curricular stipulations, as it was expressed in two cases, have the most lasting effect on the innovative activities in schools and ensure further implementation of the innovations.

However, generalising statements can not be made on the basis of the available data. There is further need for research. The Survey SITES-Module 3 will build upon the results obtained from the first two SITES modules. The distinguishing components of SITES-Module 3 are a school/teacher survey and an optional student survey. Teachers will be asked about their attitudes, training and past experiences in respect of technology, and their classroom practices. The student survey will include indicators of knowledge, attitudes, exposure to different learning applications, and the use of ICT in the home (see http://www.sitesm2.org).

\section{REFERENCES}

Hunneshagen, H., Schulz-Zander, R. and Weinreich, F. (2000) Schulen am Netz: Veränderung von Lehr- und Lernprozessen durch den Einsatz neuer Medien. In Jahrbuch der Schulentwicklung. Band 11. Weinheim, pp. 155-180.

Pelgrum, W. J., Anderson, R. E. (eds.) ICT and the emerging paradigm for life-long learning. IEA, Amsterdam.

Schulz-Zander, R. (2001) Using New Media for Learning in Schools. In Futures of Education. Essays from an Interdisciplinary Symposium. Bern. pp. 83-101. 